\title{
Recent developments in cheese cultures with protective and probiotic functionalities
}

\author{
Journal Article \\ Author(s): \\ Grattepanche, Frank; Miescher-Schwenninger, Susanne; Meile, Leo; Lacroix, Christophe \\ Publication date: \\ 2008 \\ Permanent link: \\ https://doi.org/10.3929/ethz-b-000011666 \\ Rights / license: \\ In Copyright - Non-Commercial Use Permitted \\ Originally published in: \\ Dairy Science \& Technology 88(4-5), https://doi.org/10.1051/dst:2008013
}




\title{
Recent developments in cheese cultures with protective and probiotic functionalities
}

\author{
Franck GRATTEPANCHE, Susanne MiESCHER-SCHWENNINGER, \\ Leo MEILE, Christophe LACROIX*
}

ETH Zurich, Laboratory of Food Biotechnology, Institute of Food Science and Nutrition, Schmelzbergstrasse 7, Zürich, Switzerland

\begin{abstract}
Microorganisms play essential roles in the manufacture and ripening of cheese, largely contributing to the development of organoleptic properties by their metabolism and varied enzymatic activities, and to microbiological safety through barrier effects of complex microflora and production of several low-molecular-weight antimicrobial compounds. Although extensive research has been done on bacteriocins of cheese bacteria for controlling pathogens in cheese, until now only few applications have emerged. The control of spoilage yeasts and moulds has been traditionally done by chemical additives, but the application of new antifungal protective cultures is very promising, especially for the cheese industry. It has also been recently shown that naturally established cheese microflora can efficiently prevent the growth of pathogenic or spoilage microorganisms. Cheese is also a very suitable but underused carrier for the delivery of probiotic bacteria, conferring health benefits on the host, with specific advantages compared with fermented milks and yoghurts such as high cell viability. This review addresses the latest developments in applications of protective cultures (with bacteriocin and antifungal activities) or microflora with barrier effects, and probiotic cultures for the production of high quality, safe and "healthy" cheese, as well as emphasizing some of the underlying challenges and possible solutions. Furthermore, new safety criteria for food cultures relating to the presence and transferability of antibiotic resistance genes are discussed.
\end{abstract}

cheese / bacteriocin / antifungal / probiotics / antibiotic resistance / technology

\begin{abstract}
摘要 - 具有保护和移哨功能的干酪发酵剂的研究截展。微生物在干酪的制造和成熟中起 着关键性的作用, 微生物的代谢产物和酶的活性赋予干酪的感官品质, 复杂微生物菌群的阻 隔效应和产生的一些小分子抗菌化合物是干酪微生物安全的保障。度管关于细菌素用于控 制干酪中病原菌的报道很多, 但到目前为止该技术的实际应用还是非常有限。控制干酪中腐 败酵母菌和霉菌的传统方法还是添加化学防腐剂, 因此, 有必要开发一些具有抗真菌作用, 特 别是适用于干酪生产的保护性发酵剂。最新的研究结果表明, 天然干酪中形成的微生物菌群 可以有效地防止一些病原微生物和腐败微生物的生长。与富含高活力细菌的发酵乳和酸乳 相比, 干酪还是一种益生菌很好的载体和传递者, 但没引起足够重视, 它有利于人体吸收其中 有益健康的成分。本文论述了能产生细菌素和抗真菌的保护性发酵剂或具有阻隔效应的微 生物菌群; 能够生产高质量、安全和有益健康干酪的益生菌发酵剂在干酪生产中应用的最新 进展以及在工业化生产中存在的问题。此外, 本文还讨论了食品发酵剂中抗生素抗性基因存 在和转移的安全标准。
\end{abstract}

干酪 / 细菌素 / 抗真菌 / 益生菌 / 抗生素的抗性 / 技术

*Corresponding author (通讯作者): christophe.lacroix@ilw.agrl.ethz.ch 


\begin{abstract}
Résumé - Avancées des connaissances sur les cultures à activité protectrice et probiotique pour des applications fromagères. Les microorganismes jouent un rôle essentiel dans la préparation et l'affinage des fromages en contribuant de façon importante au développement des propriétés organoleptiques par leur métabolisme et la grande variété de leurs activités enzymatiques, et à la sécurité microbiologique du produit à travers les effets barrières des microflores complexes et/ou la production de composés antimicrobiens de faibles poids moléculaires. De nombreux travaux de recherche ont été réalisés sur les bactériocines produites par des bactéries isolées de fromages pour contrôler le développement de microorganismes pathogènes. Cependant, très peu d'applications sont issues de ces travaux. Le développement des levures et moisissures nuisibles à la qualité des fromages est traditionnellement contrôlé par des additifs chimiques mais leur remplacement par des cultures protectrices antifongiques semble prometteur. Des études ont récemment rapporté le potentiel de flores naturellement établies sur des fromages pour le contrôle de flores pathogènes et de dégradation. Les fromages constituent également un vecteur adéquat, mais sous-exploité, pour les bactéries probiotiques conférant un bénéfice santé pour le consommateur. Les fromages permettent notamment de maintenir un meilleur taux de viabilité de ces bactéries comparativement à d'autres matrices telles que les yoghourts et laits fermentés. Cette revue fait le point sur les derniers développements sur les cultures protectrices (productrices de bactériocines, à activité antifongique ou à effets barrières) et probiotiques pour la production de fromages de haute qualité organoleptique et microbiologique, et ayant un effet bénéfique sur la santé du consommateur. Les contraintes technologiques associées à l'utilisation de ces cultures sont également abordées et des solutions proposées. De nouveaux critères pour la sélection de cultures microbiennes destinées à un usage alimentaire et portant sur la présence et le transfert de gènes de résistance aux antibiotiques sont également soulignés.
\end{abstract}

\title{
fromage / bactériocine / antifongique / probiotique / antibiorésistance / technologie
}

\section{INTRODUCTION}

The many activities of starter and ripening cultures are central for quality and microbiological safety of cheese. Lactic acid bacteria (LAB) are currently almost always added to cheese milk to produce lactic acid from lactose and contribute to biochemical changes during ripening and develop the characteristics of cheese. Several beneficial health effects related to the consumption of some LAB (called probiotic culture) have also been demonstrated. This potential has been largely exploited in functional dairy foods, mainly yoghurt and fermented milks. Although numerous studies have been devoted to incorporation of probiotic cultures into cheese, few probiotic cheeses are commercially produced.

On the other hand, a large variety of other microorganisms originating from many sources (milk, equipment, ripening rooms, human) and growing in the mass and on the surface of cheese also participate in cheese and greatly contribute to the characteristics and diversity of cheese.
This microbiota, which is relatively difficult to control, may also be contaminated by spoilage and/or pathogenic microorganisms and thereby, be a source of undesired contaminants for cheese. In contrast, cultures isolated from cheese or milk have a protective effect against the development of contaminants. The implementation by the cheese industry of such protective cultures could contribute with other classical measures (e.g. milk pasteurization, use of defined starter) to control the development of undesired microorganisms and further improve quality and safety of cheese.

In this review, the latest developments in the application of protective and probiotic cultures for the production of high quality, safe and "healthy" cheese have been reviewed, with underlying challenges and possible solutions.

\section{PROTECTIVE CULTURES IN CHEESE}

The implementation in the nineties of the Hazard Analysis Critical Control Point 
plan and other preventive measures in the cheese industry have greatly contributed to the reduction of the incidence of foodborne diseases related to cheese consumption. For example, during the period 19931996, the number of dairy products highly contaminated by Listeria monocytogenes (i.e. $\geqslant 100 \mathrm{cfu} \cdot \mathrm{g}^{-1}$ ) in France decreased by $41 \%$ [64]. However, a recent study on retail cheeses in the UK has shown that 5 and $4 \%$ of cheeses made from unpasteurized (including thermized milk) and pasteurized milk, respectively, were of unsatisfactory or borderline quality according to $\mathrm{EC}$ recommendations 2004/24 and 2005/175 for the presence of Salmonella, Staphylococcus aureus, Escherichia coli and L. monocytogenes [82]. A cheese with microbiological borderline quality can also be rapidly considered unsatisfactory if stored under inappropriate conditions at home. Yeasts and moulds are also common, sometimes major, spoilage organisms of food products, especially fermented milk products and cheeses. These organisms, which cause severe economic losses and significantly reduce the shelf life of products, may constitute a health hazard due to the production of mycotoxins [47,48, 129]. Therefore, there is a real need to enhance the control of microbiological safety of cheese from milk to the consumer, and this can be achieved by microbial cultures with antimicrobial features and protective effects in cheese.

\subsection{Bacteriocins and bacteriocinogenic strains}

In the last two decades, several studies have demonstrated the potential of bacteriocins to control growth of pathogenic microorganisms in food products [26]. Bacteriocins are peptides with antimicrobial activity produced by a wide diversity of bacteria. To date, most of the identified Gram-positive bacteriocins are produced by $\mathrm{LAB}$, among which there are generally recognized as safe (GRAS) organisms used for milk fermentations [66]. Moreover, bacteriocins can be rapidly degraded by proteases in the gastrointestinal tract and therefore they should not interfere with human gut microbiota [12]. Finally, bacteriocins produced in situ by food-grade bacteria do not have to be indicated on the product label. Most research on bacteriocins in cheese have targeted the control of L. monocytogenes, or other listeria species used as model for this pathogen, and clostridia spores responsible for late blowing defects in semi-hard and hard cheeses.

\subsubsection{The "classical" bacteriocins for cheese}

Nisin, a class I bacteriocin $(<5 \mathrm{kDa}$ peptides containing unusual lanthionine amino acids) produced by lactococci is the best documented bacteriocin of LAB and remains a model for the development of other bacteriocins. To date, nisin, as a food additive, is the only bacteriocin that has received regulatory approval from the US Food and Drug Administration and European Union (listed as E234) and can be labeled as a "natural preservative". Its broad activity spectrum includes listeria, enterococci, staphylococci, streptococci, clostridia, Campylobacter jejuni, Helicobacter pylori and antibiotic-resistant strains of Neisseria gonorrhoeae [94, 128]. However, the stability of nisin is highly dependent on environmental conditions, in particular $\mathrm{pH}$, and this limits its use to acidic foods [116]. In addition, nisin can be degraded by proteolytic enzymes in cheese, leading to a significant activity decrease during ripening. For example, Benech et al. [8] showed that only $12 \%$ of the initial activity produced by a nisinogenic starter remained in Cheddar cheese after 6 months of ripening. 
However, encapsulation of purified nisin into liposomes allowed the retention of $90 \%$ of initial nisin activity and thereby, resulted in an improved control of Listeria innoсиа populations in artificially contaminated cheese during ripening [8]. However, until now only few applications of nisin in the cheese industry have emerged, as summarized in recent reviews $[21,55$, 130].

In contrast to nisin, lacticin 3147 , a twocomponent broad-spectrum antimicrobial peptide produced by Lactococcus lactis subsp. lactis DPC3147 showed high stability over a wide range of $\mathrm{pH}$ [117]. No decrease in in situ produced lacticin activity was detected in Cheddar cheese over 6 months of ripening [119]. However, the application of the lacticin 3147 producer strain on surfaces of smear-ripened cheese as a pretreatment for controlling L. monocytogenes contamination was not effective [102].

Pediocin AcH (also known as pediocin PA-1 or SJ-1) is another broad-spectrum anti-listerial bacteriocin that belongs to class II (non-modified heat-stable peptides $<10 \mathrm{kDa}$ ). It is produced mainly by Pediococcus acidilactici [39], a minor population in many cheeses. However, Lactobacillus plantarum WHE (commercially available as ALC 01, anti-listerial culture, Danisco, Germany) isolated from Munster cheese was also shown to produce pediocin [40]. Production of pediocin $\mathrm{AcH}$ by $P$. acidilactici $\mathrm{H}$ was considerably reduced when final medium $\mathrm{pH}$ exceeded 5.0. In contrast, bacteriocin production by Lb. plantarum WHE 92 was not affected for $\mathrm{pH}$ values up to 6.0, which is a clear advantage for cheese application [40]. Spraying a cell suspension of $L b$. plantarum WHE 92 on surfaces of Munster cheese at the beginning of ripening inhibited growth of L. monocytogenes for 21 days [41]. However, Loessner et al. [83] stressed the risk of development of resistance when pediocin $\mathrm{AcH}$ or the producer strain is used to control L. monocytogenes on cheese surfaces.

\subsubsection{Newly developed bacteriocins for cheese applications}

In recent years, several other bacteriocins with potential use in cheese have been reported. Streptococcus and Enterococcus, two genera with particular relevance in cheese manufacture, also produce a large diversity of bacteriocins [99].

Thermophilin, produced by some strains of Streptococcus thermophilus, is a class II bacteriocin with inhibitory activity against Streptococcus, Enterococcus, Lactococcus, Bacillus and Listeria [51]. Streptococcus macedonicus is a relatively new species first isolated from Kasseri, a Greek hard-cooked cheese [137]. Macedocin, produced by Str. macedonicus ACA-DC 198, belongs to the lantibiotic bacteriocins (Class I) and inhibits several LAB as well as Clostridium tyrobutyricum [59]. C. tyrobutyricum is responsible for large defects in semi-hard and hard cheeses, such as Swiss-type or Gouda, due to high production of butyric and acetic acid, $\mathrm{CO}_{2}$ and $\mathrm{H}_{2}$ from fermentation of lactate, leading to significant flavor defects and late cheese blowing [6]. Germination of Clostridia spores can be inhibited by additives such as nitrate, lysozyme or nisin, but their uses can be restricted by local regulations [6]. Therefore, the use of the macedocin producer strain as adjunct culture could be a relevant alternative for controlling Clostridia development. Unlike nisinogenic lactococci, Str. macedonicus is not inhibited by the cooking step of the manufacture process, and macedocin is stable over a wide range of $\mathrm{pH}$ and upon prolonged fermentation [138]. Recently, Anastasiou et al. [4] evaluated the performance of Str. macedonicus ACA-DC 198 used as sole starter or adjunct culture in the production of Kasseri cheese from pasteurized milk. 
After some changes in the process (i.e. time to reach a $\mathrm{pH}$ of 5.2 in the drained curd and temperature/duration of ripening), no major effects were observed on microbiological, physicochemical or sensorial characteristics of cheeses made with Str. thermophilus ACA-DC 198 alone or mixed with a commercial starter culture compared with control cheese with only commercial starter [4]. Furthermore, Str. macedonicus ACA-DC 198 was used as starter or adjunct culture and macedocin was detected until the end of cheese ripening (90 days) [4]. However, the efficiency of macedocin inhibiting Clostridia in situ has not yet been tested in cheese.

Enterococci are used as starter or nonstarter lactic acid bacteria (NSLAB) in many traditional Mediterranean cheeses, where they greatly contribute to the development of organoleptic properties during ripening through proteolysis, lipolysis and breakdown of citrate into aroma compounds [60]. Although some members of the Enterococcus genus are also pathogenic and involved in the transfer of antibiotic resistance and/or virulence factors, others are considered safe and even used as probiotics [52]. Many enterococci can produce bacteriocins belonging exclusively to the heat-stable, non-lantibiotic class II, with the exception of cytolysin, a two-peptide lantibiotic (Class I) associated with virulence of some Enterococcus faecalis strains due to its hemolytic activity [99]. Nuñez et al. [101] have investigated the inhibition of two L. monocytogenes strains by enterocin 4, produced in situ by $E$. faecalis INIA 4 during the manufacture and ripening of Manchego cheese. The population of L. monocytogenes Ohio, initially at $10^{5}$ cells per $\mathrm{mL}$ in raw milk, decreased to less than $10^{2}$ cells per gram of curd $8 \mathrm{~h}$ after the start of manufacture when E. faecalis INIA 4 was used as sole starter or adjunct culture. From ripening days 2 to $60, L$. monocytogenes Ohio was only recovered in cheeses manufactured with $E$. faecalis INIA 4, with or without commercial culture, after an enrichment procedure of $25 \mathrm{~g}$ of cheese sample [101]. In contrast, the population of L. monocytogenes Ohio in control cheeses remained stable at $3.9 \times 10^{4}$ cells per gram. However, E. faecalis INIA 4 as sole starter failed to inhibit growth of L. monocytogenes Scott A under the same conditions.

Bactericidal synergism between heat pretreatment $\left(65^{\circ} \mathrm{C}, 5 \mathrm{~min}\right)$ and the enterocin AS-48 produced by E. faecalis A-48-32 was shown on inhibition of $S$. aureus in skimmed milk [97]. Compared with acidified skimmed milk a lower efficacy was measured in cheese when $E$. faecalis A-48-32 and Enterococcus faecium UJA32-81, both enterocin AS-38 producers, were used as starter or adjunct culture, to inhibit growth of S. aureus [97]. This result was tentatively explained by a lower production of enterocin AS-38 in cheese and/or difference in bacteriocin activity due to cheese matrix and temperature conditions (i.e. $28{ }^{\circ} \mathrm{C}$ for acidified skimmed milk and $4{ }^{\circ} \mathrm{C}$ for cheese ripening) [97]. Another important factor, $\mathrm{pH}$, may have also influenced bacteriocin activity but was not reported in the study.

To conclude this section, the relevance of bacteriocinogenic strains as "protective cultures" varies among the different studies. Indeed, the efficacy of a bacteriocin producer or bacteriocin with high potential in simple experimental set-up conditions (e.g. synthetic medium, controlled temperature and $\mathrm{pH}$ ) to control growth of pathogens can be very different when used in cheese due to several factors: competition with the starter culture, complex interactions between the bacteriocin and cheese matrix, presence of inhibitors (e.g. proteases), and/or non-optimal conditions (e.g. $\mathrm{pH}$, temperature) for growth and bacteriocin synthesis. In addition, cheese composition may also greatly differ from core to surface in terms of microflora diversity, environmental conditions, particularly salt 
and water contents, and $\mathrm{pH}$. Thus, bacteriocin production and efficiency can greatly vary within cheese. Bacteriocinogenic strains used as starter or adjunct culture must also show good growth in milk and/or cheese since bacteriocin production is usually directly correlated with final biomass.

Safety considerations using bacteriocins or their producer strains is an important issue since cross-resistances between different classes of bacteriocins and/or antibiotics have already been reported [74, 98]. Moreover, some bacteriocinogenic strains also belong to genera or species (e.g. enterococci) which include pathogenic strains. Applications of such strains at high levels in cheese should be carefully assessed for the risk to benefit ratio. Solutions proposed to overcome these major drawbacks will be discussed below (Sect. 5). Finally, the balance of the microflora of cheese, a key priority for proper ripening and final quality, can be affected by bacteriocins or bacteriocinogenic strains; this problem should be carefully assessed for each cheese type as discussed below.

\subsubsection{Impact of bacteriocins and bacteriocinogenic strains on cheese ripening}

The microflora of cheese, through its diverse metabolic activities and release of enzymes, plays an important role in the development of typical texture, flavor and appearance of ripened cheeses. Only GRAS bacteria for specific food uses can be incorporated in dairy products. For in situ bacteriocin production in cheese, the strains must also be able to grow at high levels and/or be metabolically active in the cheese environment. Therefore, only bacteriocins from LAB, generally isolated from cheese, have been used. Bacteriocins, most of them with a narrow, and some like nisin and pediocin with a broader activity spectrum, are active on bacteria closely related to the producer strain or confined to the same ecological niche [75]. Thus, the presence of bacteriocin, produced in situ or added, can disrupt the natural balance and dynamics of the cheese microflora, including starter cultures.

The acidifying capacity of nisintolerant lactococci was not significantly affected by the presence of a nisinogenic strain, whereas a significant decrease was observed for a commercial culture and nisin-sensitive lactococci during growth in milk [8]. Benech et al. [7] studied the textural, physicochemical and sensory attributes of Cheddar cheese made with a mixed culture containing Lactococcus lactis subsp. lactis biovar. diacetylactis UL719 and two nisin-tolerant lactococci. After 6 months of ripening, rheological properties were not significantly different while proteolysis, lipolysis and formation of hydrophilic and hydrophobic peptides increased in cheese containing the nisin $\mathrm{Z}$ producer compared with control cheese [7]. Enzymatic capabilities of $L c$. diacetylactis UL719 cells or autolysis of a nisin-sensitive subpopulation of the starter may be responsible for proteolysis in cheese containing the bacteriocinogenic strain [7]. In this study, the two nisin-tolerant lactococci were also selected for their high acidifying capacity in milk. However, for cheeses produced using these two strains, in combination or not with Lc. diacetylactis UL719, a bitter off-flavor and an acidic taste were observed [7], probably due to a low amino-peptidasic activity of these strains compared with commercial starter cultures. Nevertheless, cheese bitterness could be corrected and flavor improved by incorporating a high proteolytic strain, Lactobacillus casei subsp. casei L2A, in the mixed lactococci starter containing the nisin $\mathrm{Z}$ producer [7]. Similar results were recently reported for Hispanico cheese manufactured using a lacticin 481 producing strain, Lc. lactis INIA 639, a non-bacteriocinogenic strain, 
Lc. lactis INIA 437, and Lactobacillus helveticus with high amino-peptidase activity and sensitive to lacticin 481 [57]. Analysis of volatile compounds also showed an enhanced production of 2-methylpropanal, 2-methylbutanal, ethanol, 1-propanol, ethyl acetate, ethyl butanoate and ethyl hexanoate in lacticin cheeses, which reached higher scores for aroma quality and intensity compared with control cheese made with both starter and adjunct culture [56].

Bacteriocins have been shown to induce lysis of sensitive starter cultures, leading to a fast release of intracellular enzymes which enhance cheese flavor development $[86,88,95]$. Bacteriocins may also facilitate diffusion in the cells of molecules, such as amino acids, through membrane permeabilization. The increased aminoacid pool may lead to an increased rate of transamination and formation of $\alpha$-keto acids which can be further degraded enzymatically into flavor compounds [87].

\subsection{Protective cultures producing non-proteinaceous low- molecular-weight antimicrobial compounds}

Recently, antifungal cultures have gained importance for cheese applications although limited work has been done in this field. The antifungal properties of LAB have been recently reviewed by Schnürer and Magnusson [125]. The assessment of cheese spoilage by yeasts and moulds is complicated because fungal activity during ripening can be either needed or detrimental to product quality, depending on the type of cheese and microorganisms [48]. Spoilage of cheese due to fungal growth is caused by the production of volatile compounds, leading to off-flavors, and also mycotoxin accumulation, which may promote allergies [47, 129]. Penicillium spp. and Aspergillus spp. are important spoilage moulds in preservative-free hard, semi-hard and semi-soft cheeses, whereas Candida spp., Kluyveromyces marxianus and Pichia spp. are main contaminants in unripened soft cheeses [47,48].

The control of spoilage yeasts and moulds is traditionally done by chemical additives such as sorbic and benzoic acids, which both have a broad activity spectrum. Furthermore, the antibiotic natamycin produced by Streptomyces natalensis is effective against fungi and is used as a common preservative on hard cheese surfaces [22, 34]. In contrast, consumers are increasingly demanding high quality, safe and mildly processed foods with long shelf life and low or no addition of chemical preservatives. Furthermore, fungi also showed an increased resistance to antibiotics and chemical preservatives such as sorbic and benzoic acids [18]. Thus, the application of antifungal protective food cultures has a high potential, especially in dairy products such as cheeses or fermented milks.

So far, only a few antifungal protective cultures are commercialized and their applications are still emerging, especially for dairy products but also for other foods and feeds (Tab. I). Two protective cultures are currently marketed by Danisco (Danisco, Copenhagen, Denmark) as the HOLDBAC ${ }^{\mathrm{TM}}$ range, combining two strains of Propionibacterium freudenreichii subsp. shermanii JS and Lactobacillus rhamnosus LC705 [133] or Lactobacillus paracasei SM20 [91,92]. Both cultures have been successfully tested in yoghurt and on the surface of hard cheese to prevent spoilage by yeasts and moulds [91].

In contrast to antibacterial peptides, only little is known about antifungal mechanisms. So far, research has mainly been directed towards identifying different antifungal metabolites produced in simple in vitro fermentations, but detected antifungal metabolites were not solely responsible for antifungal features of a particular strain or culture. Due 


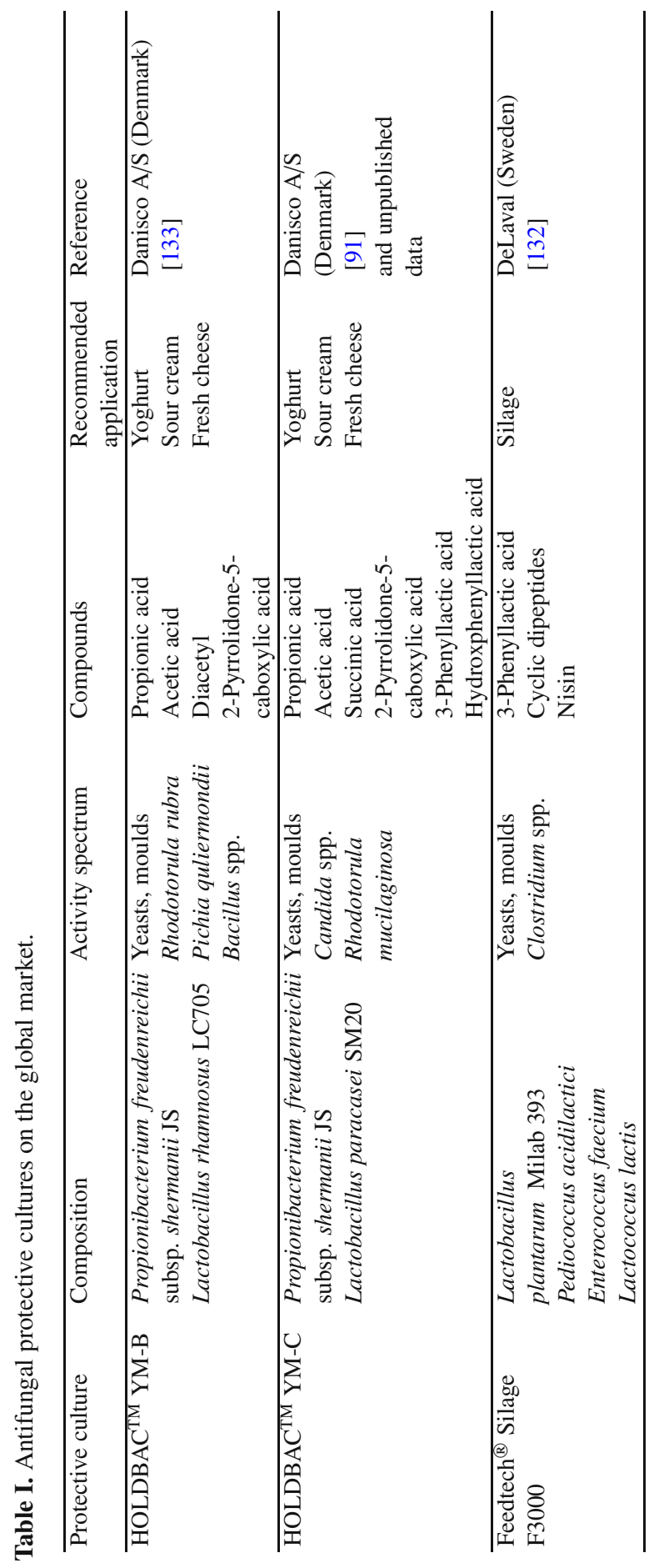


to complex and synergistic interactions between different low-molecular-weight compounds and likely cell-to-cell interactions, the overall mechanisms are difficult to elucidate [125]. Recently, we identified the production of several antimicrobials, including 2-pyrrolidone-5-carboxylic acid, 3-phenyllactic acid, hydroxyphenyllactic acid, and succinic acid besides propionic and acetic acids, during fermentations of $L b$. paracasei SM20 and Propionibacterium jensenii SM11 in whey-based medium (unpublished data). Similarly, Lb. rhamnosus LC705 was shown to produce 2-pyrrolidone5-carboxylic acid [140]. Furthermore, mixtures including acetic, caproic, formic, propionic, butyric, $n$-valeric, and benzoic acids, as well as 3-hydroxy fatty acids, proteinaceous compounds and cyclic dipeptides were described as antifungal compounds of LAB [29, 84, 100, 127, 132]. One common characteristic was that all these compounds had to be present at low concentrations in contrast to high minimal inhibitory concentrations for fungi, confirming the complexity of antifungal mechanisms [132, 140].

The application of antifungal protective cultures is very promising, especially for the cheese industry. Several strains have been recently developed for cheese applications but further research is required to elucidate their mechanisms, reduce costs and for implementation by the industry. High effectiveness of protective cultures is often related to high inoculation levels, which can affect food quality and increase costs compared with traditional chemical preservation [91]. Clearly, careful optimization of antifungal systems and their applications are required.

\subsection{Barrier effects of complex cheese microbiota}

Cheese surface consortia are known to be complex ecosystems, exhibiting high species and strain diversity of bacteria and eukaryotes. Recently developed molecular tools such as pulsed field gel electrophoresis (PFGE), which is a culturedependent method, temporal temperature gel electrophoresis (TTGE), denaturing gradient gel electrophoresis (DGGE), single strand conformation polymorphism (SSCP), and terminal restriction fragment length polymorphism- (TRFLP-) or length heterogeneity- (LH-) PCR have been successfully used to explore diversity and dynamics of cheese microflora [30, 35, 49, $80,103,113,114]$. Throughout cheese manufacturing and ripening, the development of the microflora is influenced by negative interactions between the different microbial populations, such as competition for nutrients, as well as stimulating interactions, such as $\mathrm{pH}$ increase and production of growth factors [96]. Both bacterial and eukaryotic populations evolve, with some species disappearing and others becoming predominant.

Naturally established cheese microflora were found to be more or less permissive for the growth of pathogenic or spoilage microorganisms $[13,85,93,124]$. The inhibitory activity was related to biodiversity and/or dynamics of the microflora because no antimicrobial activity was detected with pure cultures of the isolated strains.

Different hypotheses can be formulated to explain the antimicrobial activity of complex consortia. Certain factors associated with their metabolism (e.g. organic acids and $\mathrm{H}_{2} \mathrm{O}_{2}$ production, nutrient depletion) together with cheese manufacture parameters (e.g. temperature, salt concentration) might exert synergic actions, inhibiting pathogenic or spoilage microorganisms. It is also well known that bacteriocin synthesis can be regulated by quorum sensing systems [62]. In this case, signaling molecules produced by one population of cheese consortia are believed to trigger bacteriocin production by another 
population, thus explaining the absence of anti-microbial activity of pure cultures.

The selection of complex surface microflora to control the growth of spoilage and pathogenic microorganisms in cheese appears to be a promising avenue because no modification of process is required. However, further studies are needed to understand better mechanisms contributing to antimicrobial activity. The controlled propagation-production of such microflora for large-scale applications is a technological challenge, as presented below.

\section{PROBIOTIC CULTURES IN CHEESE}

Probiotics are defined by the FAO/WHO [45] as "live microorganisms which when administered in adequate amounts confer a health benefit on the host". The beneficial effects in treatment and prevention of various diseases or gut disorders such as inflammatory bowel disease or lactose intolerance are greatly debated in the literature [106]. Probiotic microorganisms include several genera of bacteria and yeasts [68], and among those, strains of enterococci, lactobacilli and propionibacteria are important for manufacturing some cheeses [52, 90, 108], and well adapted to the cheese environment. On the other hand, bifidobacteria and Lactobacillus acidophilus are most used in functional dairy foods containing probiotics, especially milk, yoghurt, ice cream and desserts [20]. However, conditions encountered in these products are very different from those of their natural habitat, the gastrointestinal tract of humans and animals. Thus, product composition can have deleterious effects on their viability, which is one of the most important prerequisites for beneficial health effects [106]. Due to its limited acidity, low oxygen level, high lipid content and low storage temperature, cheese is a suitable carrier for delivering live probiotic bacteria [15].

\subsection{Characteristics of probiotic bifidobacteria and lactobacilli related to their viability in cheeses}

Viability of probiotics is a key parameter for efficacy of probiotic products. Although the amount of cells required to produce beneficial health effects is not known, some authors have suggested a daily intake of at least $10^{8}-10^{9}$ viable cells as the minimum intake to provide a therapeutic effect [118]. A minimum level of $10^{6} \mathrm{cfu}$ of probiotic bacteria per gram of product at the time of consumption is generally accepted and selected to provide bacterial concentrations that are technologically attainable and cost-effective $[79,123]$. According to this criterion, most cheeses seem to be suitable carriers for probiotic bacteria, as indicated by the high stability of viable cell counts reported for many cheeses during storage (Tab. II).

Probiotic bifidobacteria and lactobacilli of gut origin are generally classified as strictly anaerobic or microaerophilic but their resistance to oxygen is strainand species-dependent [134]. They usually show poor resistance under prolonged acidic conditions, with lactobacilli being less affected than bifidobacteria [20]. These characteristics explain the higher survival of probiotic cultures in cheese compared with other dairy products, in particular yoghurts and fermented milks [72, 126]. Indeed, yoghurt has an initial $\mathrm{pH}$ of about 4.1-4.4 that decreases to 3.84.2 during refrigerated storage due to lactic acid production by Lactobacillus delbrueckii subsp. bulgaricus. On the other hand, the curd of soft cheeses has a $\mathrm{pH}$ below 5.0 after production (about 4.5 for Camembert cheese) but it increases rapidly during ripening. In 35-day 
ripened Camembert cheese, $\mathrm{pH}$ in the core and the rind reached high values, around 6.8 and 7.5, respectively [2]. The $\mathrm{pH}$ of hard and semi-hard cheeses, generally above 5.0 after production, remained relatively constant throughout the ripening period [23]. Furthermore, the cheese core can be considered as an anaerobic environment with very low redox potential $\left(E_{h}\right)$ of about $-250 \mathrm{mV}$ [9]. The redox potential of Camembert cheese during ripening has been shown to increase from +330 to $+360 \mathrm{mV}$ on the surface and decrease from -300 to $-360 \mathrm{mV}$ in the core [2]. In contrast, $\mathrm{E}_{\mathrm{h}}$ is positive in yoghurt and increases with storage time above $+120 \mathrm{mV}[32,33]$. Other parameters have been reported to influence probiotic viability in cheese, such as temperature and duration of ripening, presence of NSLAB with antagonistic activities, milk pasteurization and salt content $[63,104,105,112$, 141].

Several bifidobacteria strains have been successfully incorporated into cheeses with no major changes in the process (Tab. II). This is different from yoghurt, where the incorporation of bifidobacteria is generally limited to Bifidobacterium animalis, a bacteria isolated from animals, due to its high acid and oxygen tolerance compared with human bifidobacteria [20, 72]. Because the health benefits of animal bifidobacteria have not been researched to the same extent as human species [72], cheese is a promising carrier for enlarging the range of bifidobacteria added to functional foods. Furthermore, cheese is also a suitable protective carrier against harsh stomach conditions. Vinderola et al. [139] have reported high survival for Bifidobacterium bifidum, $L b$. acidophilus and $L b$. casei added to Argentinian Fresco cheese and subjected to a $\mathrm{pH}$ of 3.0 for $3 \mathrm{~h}$ at $37{ }^{\circ} \mathrm{C}$. In an in vitro test, Cheddar cheese containing a probiotic strain of E. faecium gave greater protection to the strain exposed to porcine gastric juice at $\mathrm{pH} 2.0$ than yoghurt [58]. Cellular response of $P$. freudenreichii to technological stresses during Swiss-type cheese manufacture has also been reported to increase resistance of cells to acidic conditions [71].

However, although cheese is likely one of the best carriers for probiotics, the addition of high numbers of viable and metabolically active cells can affect product quality, especially organoleptic properties, as discussed below.

\subsection{Effects of probiotic bifidobacteria and lactobacilli on cheese quality}

The gross chemical composition of cheese (i.e. salt, protein, fat and moisture) and $\mathrm{pH}$ are generally not influenced by added probiotic bacteria $[10,11,19,28,31$, $37,61,104,105,141]$. However, in Cheddar cheese containing Bifidobacterium lactis Bb-12, Mc Brearty et al. [89] measured a higher moisture level of $40 \%$, exceeding the legal limit, compared with control cheese containing about $38 \%$ moisture. This effect, leading to low body/texture scores in sensory analysis, was explained by a rapid acidification during cheese manufacture with the starter added together with B. lactis Bb-12 [89].

Incorporation of probiotic cultures in cheese does not generally affect primary proteolysis which in many cheeses results from activity of the coagulant agent (except for high cook cheeses) and, to a lesser extent, of plasmin and subsequently, residual coagulant and enzymes from the starter microflora [131]. However, changes in secondary proteolysis and increases in free amino acid content have often been reported when probiotics were added to cheese [11, 61, 89, 104, 105]. Peptides and amino acids directly contribute to cheese flavor (such as sweet, bitter or malty) and can be precursors for the synthesis of other 


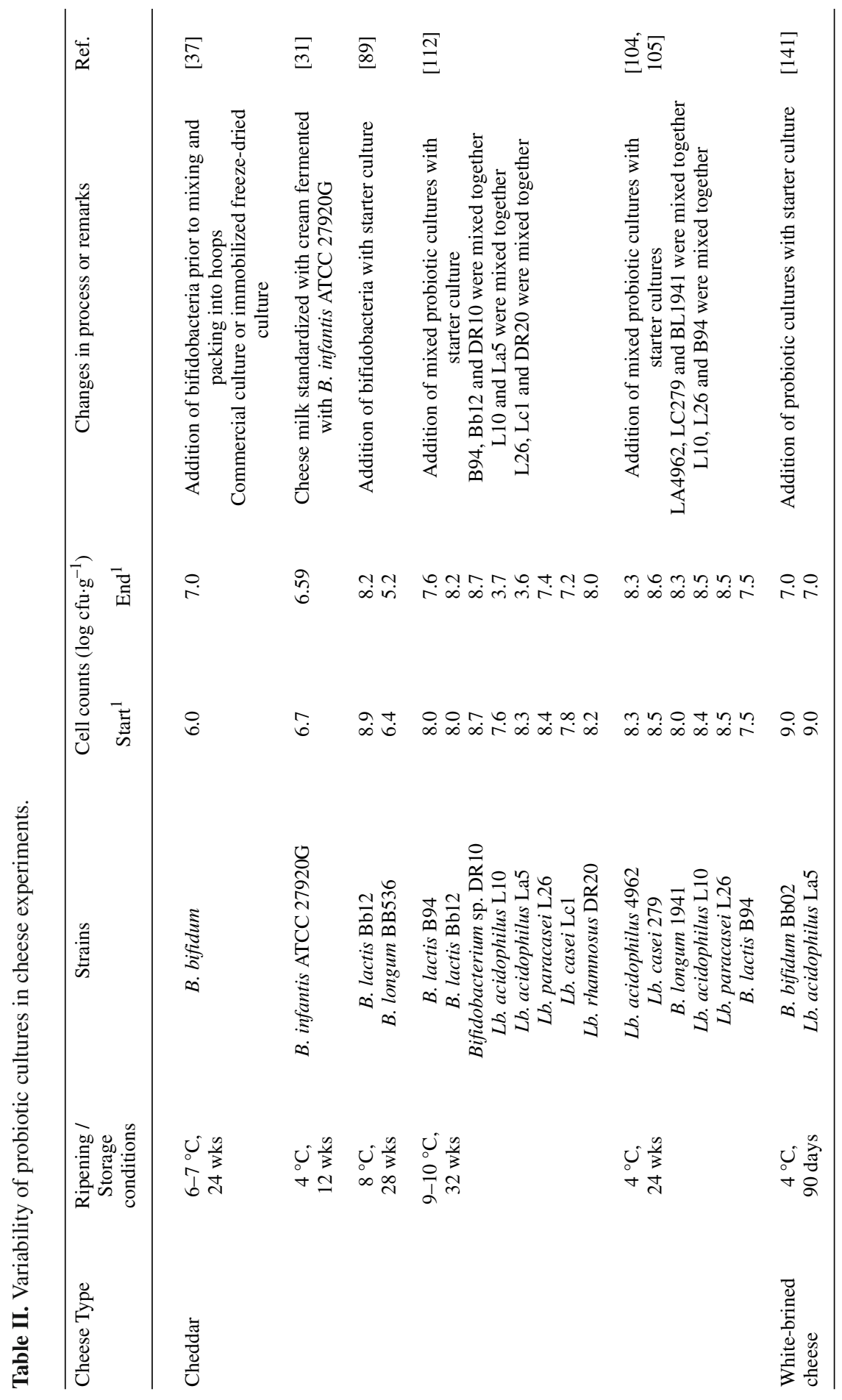


Protective and probiotic cultures for cheese

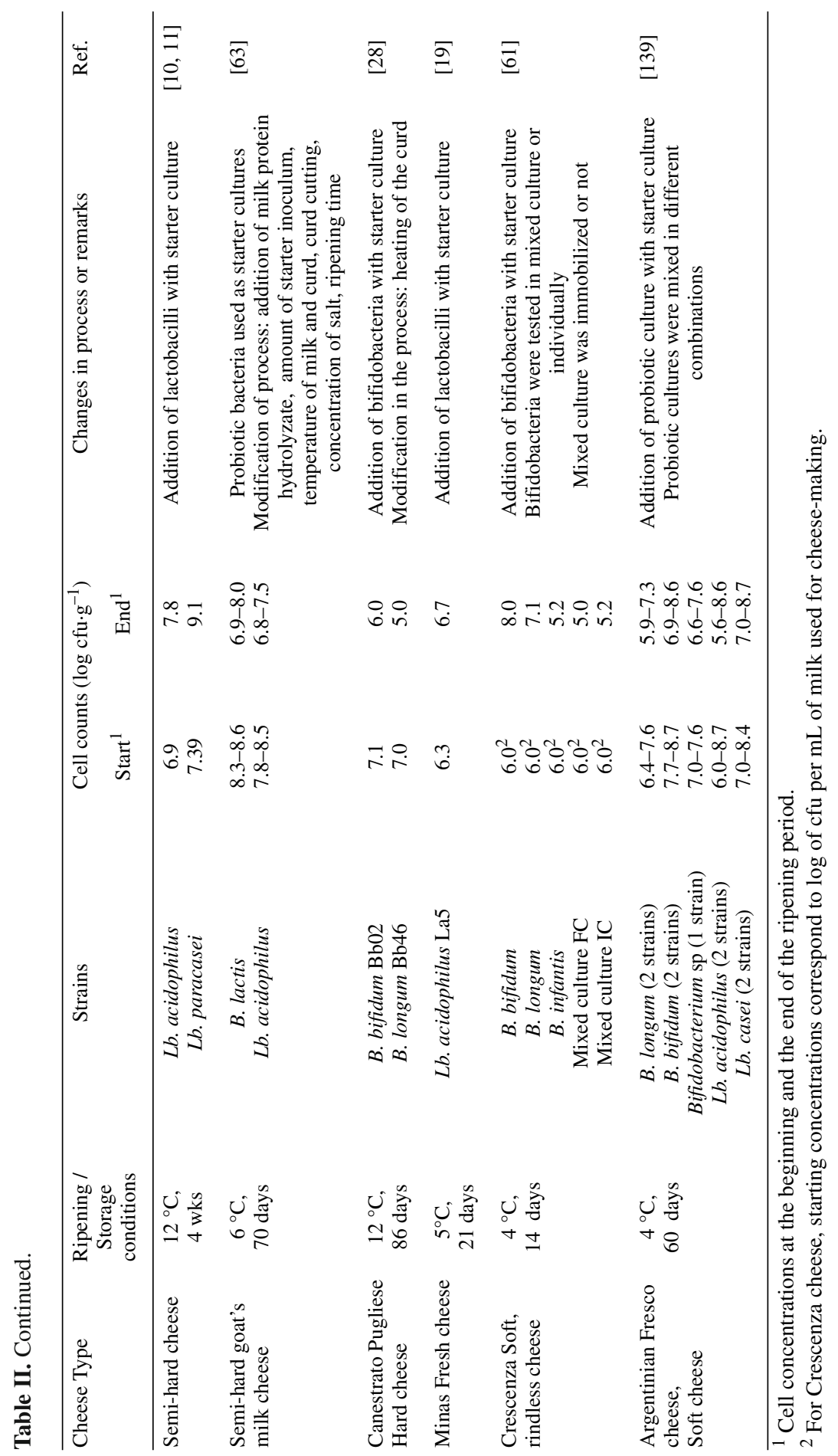


flavors or volatile aroma, resulting in offflavors [5, 128].

During ripening, lipolysis also plays an important role in the development of cheese characteristics. The addition of probiotic cultures does not seem to affect the free fatty acid profile of cheese, likely due to a higher lipolytic activity of starters and some NSLAB compared with probiotic cultures $[28,61,63]$.

Most cheeses containing probiotic lactobacilli and bifidobacteria have high acetic acid content due to heterofermentation $[28,31,61,63,89,104,105]$. Bifidobacteria produce mainly acetic and lactic acid, in a molar ratio $2: 3$, from lactose fermentation via the fructose-6-phosphate shunt pathway. Some lactobacilli can also produce acetic acid, but to a lesser extent compared with bifidobacteria [36]. Acetic acid contributes to the typical flavor of different cheeses, but excessive concentrations can also result in off-flavors $[53,120]$.

Lactose maldigestion can be alleviated by $\beta$-galactosidase activities of bifidobacteria [67]. A complete lactose hydrolysis was observed in Crescenza, Canestrato Pugliese and Cheddar-like cheeses to which bifidobacteria were added, eventually leading to a small galactose accumulation [28, 31,61].

As already reported by several authors $[15,118]$, cheese is a promising food matrix for probiotics. However, only a few probiotic cheeses have been successfully developed for the market compared with yoghurts or fermented milks. Furthermore, strain selection and possible process adjustments should be carefully evaluated to maximize probiotic cell viability during cheese manufacture and storage, as well as to limit possible changes in organoleptic properties. Finally, dairy propionibacteria which have been recently proposed as probiotics [107] could be further researched for applications as probiotic and ripening cultures, especially for Swiss-type cheeses.

\section{ANTIBIOTIC RESISTANCE}

Until recently, safety criteria for food cultures were mainly based on a long history of safe use $[54,121]$. These criteria were often considered sufficient for use of any strains belonging to a particular "safe" genus or species in cheese technology. However, it is now increasingly accepted that strains of almost any bacterial species can acquire plasmids or transposons containing antibiotic $(\mathrm{AB})$ resistance genes or virulence factors and therefore, safety considerations have to be placed on particular strains. Increasing concerns over the $\mathrm{AB}$ resistance situation in food-related bacteria are partly due to excessive use of antibiotics in both human and veterinary medicine and agriculture $[1$, $81,109]$ and to the high transferability potential of acquired $\mathrm{AB}$ resistance genes [3, $110]$. During the last decade, the hypothesis that non-pathogenic microorganisms in fermented food, e.g. LAB in cheese, can also function as reservoirs for transferable $\mathrm{AB}$ resistance determinants has been verified $[122,135]$. As a consequence, horizontal gene transfer (HGT) of such determinants to other bacteria can occur in the cheese matrix and surface and once cheese is consumed, between cheese organisms and commensal microbiota in the gastrointestinal tract. HGT by conjugation between the cheese isolate $L b$. plantarum harboring the plasmid pLFE1 with the erythromycin resistance gene $\operatorname{erm}(\mathrm{B})$ and E. faecalis was measured at high frequency in gnotobiotic rats even without selective pressure [46].

The presence of $\mathrm{AB}$ resistance genes in both isolated LAB from fermented foods, such as cheese, and LAB of human origin is the first evidence for such $\mathrm{AB}$ resistance gene transfer, as recently reviewed by Ammor et al. [3]. The best documented examples are tetracycline and erythromycin resistance genes found in enterococci in European cheeses [70, 135]. AB resistance genes were also characterized in 
cheese LAB isolates belonging to the genera Lactobacillus, Lactococcus and Leuconostoc [3]. Furthermore, transferability of $\mathrm{AB}$ resistance genes derived from plasmids and transposons of cheese LAB isolates was demonstrated in vitro between different species of LAB by conjugation on agar plates [109].

A second indication of HGT is the increasing prevalence of AB-resistant non-Enterococcus $\mathrm{LAB}$ isolates from cheeses [3,27,50,69, 109, 136]. Phenotypic analysis of $\mathrm{AB}$ resistance among $\mathrm{LAB}$ was always limited by different methodological approaches used to determine AB susceptibility-resistance breakpoints of dairy strains and bifidobacteria. The use of the micro-dilution method for determining minimal inhibitory concentrations of antibiotics in non-clinical, non-Enterococcus LAB and bifidobacteria was highly recommended $[38,76]$. Results for phenotypic resistance are then compared with the breakpoints established for the species [50]. Now available are new molecular screening tools based on microarray hybridization allowing rapid screening of $\mathrm{AB}$ resistance genes [111]. With a microarray targeting ninety different $\mathrm{AB}$ resistance determinants mainly from Gram-positive bacteria, Kastner et al. [73] showed that among thirty LAB starter strains used for cheese production, none contained acquired $\mathrm{AB}$ resistance genes, in contrast to several meat LAB starters and two probiotic cultures: Lactobacillus reuteri SD 2112 with the plasmid-encoded tetracycline resistance gene tet $(\mathrm{W})$ and the lincosamide resistance gene $\operatorname{lnu}(\mathrm{A})$; and Bifidobacterium animalis subsp. lactis DSM 10140 with tet(W).

To conclude, $\mathrm{AB}$ resistance screening of industrial cultures and novel strains should be done systematically. Strain identification by phenotypic and genotypic methods and the absence of transferable AB resistance genes and virulence factors are important criteria which will be implemented in European food legislation [42, 43]. According to criteria set by the European Food Safety Authority [44], intrinsic AB resistance or $\mathrm{AB}$ resistance due to mutation of chromosomal genes represent acceptable risks of dissemination by HGT, but acquired $\mathrm{AB}$ resistances are risk factors for public health.

\section{TECHNOLOGICAL CHALLENGES AND PROSPECTS FOR INNOVATIVE TECHNOLOGIES}

The incorporation of functional cultures in cheese must have no deleterious effects on the cheese manufacturing process and product quality. This implies that metabolic activities (e.g. lactic acid, aroma and flavor productions) of cultures with added functionalities must be similar to those of the original starter culture. On the other hand, a functional culture should not be impaired to provide the desired effect. Technological challenges and possible solutions for application of protective and probiotic cultures in cheese are discussed below.

\subsection{Challenges related to bacteriocinogenic cultures in cheese}

As discussed previously, bacteriocinogenic strains can affect the growth of starter cultures, and milk and curd acidification. Conversely, good growth of the producer strains in the presence of the starter culture is also needed because bacteriocin production is directly related to cell concentration. To overcome this major limitation, bacterial strains for starter cultures must be carefully selected. Bouksaim et al. [14] highlighted the importance of the inoculum ratio of bacteriocinogenic strains and starter cultures for controlled acidification and production in Gouda cheese. 
A very small change in the proportion of mixed culture inoculum from $0.4 / 1.4 \%$ to $0.6 / 1.4 \%$ between the nisinogenic strain (Lc. diacetylactis UL719) and Flora Danica starter led to a large increase in numbers of UL719 accompanied by changes in nisin $\mathrm{Z}$ activity in cheese, i.e. from nondetectable to 256 international units (corresponding to $6.4 \mu \mathrm{g}$ pure nisin) per gram of cheese, although composition of cheeses was similar to control cheese made with $1.4 \%$ Flora Danica only. This study clearly showed the great challenge of controlling bacteriocinogenic strain activity in cheese. The use of bacteriocin-resistant strains has also been proposed by several authors to overcome the deleterious effects of bacteriocin on acidifying capacity of starter cultures $[8,95]$. However, the selection process can be difficult, particularly in the case of cheese with complex microflora. Furthermore, other technological parameters (e.g. bacteriophage resistance of starter and bacteriocin cultures) are also important for cheese applications.

Technological properties (e.g. ability to grow and acidify in milk) and/or safety status (e.g. bacteriocinogenic strains carrying $\mathrm{AB}$ resistance and/or belonging to genus or species which includes pathogenic strains) of bacteriocinogenic strains can also limit their applications in cheese. As a possible solution, the heterologous production of bacteriocin in GRAS strains with relevant technological properties was successfully attempted $[16,115]$.

Despite extensive research done on bacteriocins and bacteriocinogenic strains, few products are commercially available, reflecting the difficulties of implementation of such protective cultures in cheese manufacturing. Although heterologous production of bacteriocins has good potential to facilitate applications of bacteriocinogenic cultures in cheese, regulatory considerations and general consumer opposition to use of genetically modified organisms in food will likely block this development.

\subsection{Innovative technologies for production of cheese cultures}

Industrial processes for food culture production, including cheese cultures and probiotics, almost exclusively use conventional batch fermentation with suspended cells cultivated separately. Separately produced cultures are eventually mixed after production to formulate commercial preparations. For bacterial surfaceripened cheeses, cheeses after salting are either inoculated with commercial defined mixed cultures containing different strains of Brevibacterium linens, Debaromyces hansenii and/or Geotrichum candidum, or in some countries are washed with smears from older cheeses ("old-young" smearing method) [17].

However, both approaches have disadvantages, such as limited biodiversity for controlled inoculation and contamination risks by undesirable contaminants for the "old-young" smearing method. The development of technologies enabling a controlled propagation of complex microflora could be very useful for controlling contamination and developing cheese surface flora, leading to high product quality and safety.

Cell immobilization has been used to perform high cell density fermentations for both cell and metabolite productions with several advantages over free-cell fermentations, including: high cell densities, reuse of biocatalysts, improved resistance to contamination and bacteriophage attack, enhancement of plasmid stability, prevention from washing-out during continuous cultures, and the physical and chemical protection of cells $[78,79]$. Recently, we developed and validated new continuous fermentation systems with immobilized human fecal microbiota to closely 
model intestinal fermentation and stably cultivate complex microbiota [24,25]. Similar approaches could be used to stabilize and propagate complex cheese surface microflora, and eventually develop dynamic fermentor models to study cheese surface ecosystems.

Current data also suggest that cell immobilization combined with continuous culture might also be used to efficiently produce, in a one-step process, functional cultures and probiotic cells with enhanced tolerance to environmental stresses and improved technological and functional characteristics [78, 79]. Recent studies with immobilized lactobacilli and continuous mixed strain cultures have reported significant physiological changes, such as a large increase in cell tolerance to nisin and low $\mathrm{pH}$, and enhanced acidification capacity of cheese cultures $[65,77]$.

\section{CONCLUSION}

Despite a great deal of basic and applied research carried out on identification, characterization and development of bacteriocinogenic strains in cheese over the past thirty years or even more, very few applications have reached the market. This situation is largely explained by the difficulty of applying bacteriocinogenic strains in the context of industrial cheese production where needs for robust and reproducible processes are high. Selection of competitive bacteriocinogenic strains in cheese environments and suitable starters with low sensitivity to the bacteriocin is a prerequisite for successful large-scale applications. Development of culture rotation to respond to bacteriophage attacks is also needed. Furthermore, strict process control is required to achieve proper growth of starter, secondary and adjunct cultures and production of uniform, high quality and safe cheese. If this can be achieved, in situ bacteriocin production could be used both to enhance microbio- logical safety of cheese and to accelerate cheese ripening. One of the most promising applications of protective cultures is on cheese surfaces where post-processing contamination is more likely to occur and no interference with starter cultures is expected. The selection and development of complex natural cheese surface microflora with protective properties against spoilage and pathogenic contaminants is especially attractive but will require development of suitable technologies for controlled propagation of complex cultures. Furthermore, the development of antifungal cultures with protective effects associated with minimal metabolism in cheese is rapidly evolving and similar concepts relying on synergistic mixtures of nonprotein low-molecular-weight metabolites could be further developed to target bacterial contaminants.

Cheese is also a very suitable but underused carrier for the delivery of probotics, with specific advantages compared to fermented milks and yoghurts for maintaining high cell viability and with potential to enlarge the range of probiotic strains used in functional dairy products. It is therefore expected that new functional cheeses will be developed on the market, eventually harboring resident cultures with probiotic features not yet characterized and exploited.

Finally, safety of food cultures will become increasingly important with the emergence and dissemination of $\mathrm{AB}$ resistance genes. In the near future cheese and probiotic cultures, like any other food cultures, will have to fulfill strict testing to guarantee the absence of acquired $\mathrm{AB}$ resistance genes with transfer potential.

\section{REFERENCES}

[1] Aarestrup F.M., Veterinary drug usage and antimicrobial resistance in bacteria of animal origin, Bas. Clin. Pharmacol. Toxicol. 96 (2005) 271-281. 
[2] Abraham S., Cachon R., Colas B., Feron G., De Coninck J., $\mathrm{E}_{\mathrm{h}}$ and $\mathrm{pH}$ gradients in Camembert cheese during ripening: measurements using microelectrodes and correlations with texture, Int. Dairy J. 17 (2007) 954-960.

[3] Ammor M.S., Florez A.B, Mayo B., Antibiotic resistance in non-enterococcal lactic acid bacteria and bifidobacteria, Food Microbiol. 24 (2007) 559-570.

[4] Anastasiou R., Georgalaki M., Manolopoulou E., Kandarakis I., De Vuyst L., Tsakalidou E., The performance of Streptococcus macedonicus ACA-DC 198 as starter culture in Kasseri cheese production, Int. Dairy J. 17 (2007) 208-217.

[5] Ardö Y., Flavour formation by amino acid catabolism, Biotechnol. Adv. 24 (2006) 238-242.

[6] Bachmann H.P., Bütikofer U., Isolini D., Swiss-type cheese, in: Roginski H. (Ed.), Encyclopedia of Dairy Science, Elsevier, Oxford, UK, 2004, pp. 363-371.

[7] Benech R.O., Kheadr E.E., Lacroix C., Fliss I., Impact of nisin producing culture and liposome-encapsulated nisin on ripening of Lactobacillus added-Cheddar cheese, J. Dairy Sci. 86 (2003) 1895-1909.

[8] Benech R.O., Kheadr E.E., Laridi R., Lacroix C., Fliss I., Inhibition of Listeria innocua in Cheddar cheese by addition of nisin $\mathrm{Z}$ in liposomes or by in situ production in mixed culture, Appl. Environ. Microbiol. 68 (2002) 3683-3690.

[9] Beresford T.P., Fitzsimons N.A., Brennan N.L., Cogan T.M., Recent advances in cheese microbiology, Int. Dairy J. 11 (2001) 259-274.

[10] Bergamini C.V., Hynes E.R., Quiberoni A., Suárez V.B., Zalazar C.A., Probiotic bacteria as adjunct starters: influence of the addition methodology on their survival in a semi-hard Argentinean cheese, Food Res. Int. 38 (2005) 597-604.

[11] Bergamini C.V., Hynes E.R., Zalazar C.A., Influence of probiotic bacteria on the proteolysis profile of a semi-hard cheese, Int. Dairy J. 16 (2006) 856-866.

[12] Bernbom N., Licht T.R., Brogren C.H., Jelle B., Johansen A.H., Badiola I., Vogensen F.K., Nørrung B., Effect of Lactococcus lactis on composition of intestinal microbiota: role of nisin, Appl. Environ. Microbiol. 72 (2006) 239-244.
[13] Bockelmann W., Willems K.P., Neve H., Heller K.H., Cultures for the ripening of smear cheeses, Int. Dairy J. 15 (2005) 719732.

[14] Bouksaim M., Lacroix C., Audet P., Simard R.E., Effects of mixed starter composition on nisin $\mathrm{Z}$ production by Lactococcus lactis subsp lactis biovar. diacetylactis UL 719 during production and ripening of Gouda cheese, Int. J. Food Microbiol. 59 (2000) 141-156.

[15] Boylston T.D., Vinderola C.G., Ghoddusi H.B., Reinheimer J.A, Incorporation of bifidobacteria into cheeses: challenges and rewards, Int. Dairy J. 14 (2004) 375-387.

[16] Brede D.A., Faye T., Stierli M.P., Dasen G., Theiler A., Nes I.F., Meile L., Holo H., Heterologous production of antimicrobial peptides in Propionibacterium freudenreichii, Appl. Environ. Microbiol. 71 (2005) 8077-8084.

[17] Brennan T.M., Cogan M., Loessner M., Scherer S., Bacterial surface-ripened cheeses, in: Fox P.F., Mc Sweeney P.L.H, Cogan T.M., Guinee T.P. (Eds.), Cheese: Major Cheese Groups, Elsevier, Oxford, UK, 2004, pp. 199-225.

[18] Brul S., Coote P., Preservative agents in foods - Mode of action and microbial resistance mechanisms, Int. J. Food Microbiol. 50 (1999) 1-17.

[19] Buriti F.C.A., da Rocha J.S., Saad S.M.I., Incorporation of Lactobacillus acidophilus in Minas fresh cheese and its implication for textural and sensorial properties during storage, Int. Dairy J. 15 (2005) 1279-1288.

[20] Champagne C., Gardner N., Roy D., Challenges in the addition of probiotic cultures to foods, Crit. Rev. Food Sci. Nutr. 45 (2005) 61-84.

[21] Cheigh C.I., Pyun Y.R., Nisin biosynthesis and its properties, Biotechnol. Lett. 27 (2005) 1641-1648.

[22] Chipley J.R., Sodium benzoate and benzoic acid, in: Davidson P.M., Branen A.L. (Eds.), Antimicrobials in Foods, Marcel Dekker Inc., New York., USA, 1993, pp. 46.

[23] Choisy C., Desmazeaud M., Gripon J.C., Lamberet G., Lenoir J., La biochimie de l'affinage, in: Eck A., Gillis J.C. (Eds.), Le Fromage, Lavoisier, Paris, 1997, pp. 86161 . 
[24] Cinquin C., Le Blay G., Fliss I., Lacroix C., Immobilization of infant fecal microbiota and utilization in an in vitro colonic fermentation model, Microb. Ecol. 48 (2004) 128138.

[25] Cinquin C., Le Blay G., Fliss I., Lacroix C., New three-stage in vitro model for infant colonic fermentation with immobilized fecal microbiota, FEMS Microbiol. Ecol. 57 (2006) 324-336.

[26] Cleveland J., Montville T.J., Nes I.F., Chikindas M.L., Bacteriocins: safe, natural antimicrobials for food preservation, Int. J. Food Microbiol. 71 (2001) 1-20.

[27] Coppola R., Succi M., Tremante P., Reale A., Salzano G., Sorrentino Z., Antibiotic susceptibility of Lactobacillus rhamnosus strains isolated from Parmegiano Reggiona cheese, Lait 85 (2005) 193-204.

[28] Corbo M.R., Albenzio M., De Angelis M., Sevi A., Gobbetti M., Microbiological and biochemical properties of Canestrato Pugliese hard cheese supplemented with bifidobacteria, J. Dairy Sci. 84 (2001) 551561.

[29] Corsetti A., Gobbetti M., Rossi J., Damiani P., Antimould activity of sourdough lactic acid bacteria: identification of a mixture of organic acids produced by Lactobacillus sanfrancisco CB1, Appl. Microbiol. Biotechnol. 50 (1998) 253-256.

[30] Cronin T., Ziino M., Condurso C., McSweeney P.L.H., Mills S., Ross R.P., Stanton C., A survey of the microbial and chemical composition of seven semiripened Provola dei Nebrodi Sicilian cheeses, J. Appl. Microbiol. 103 (2007) 1128-1139.

[31] Daigle A., Roy D., Bélanger G., Vuillemard J.C., Production of probiotic cheese (Cheddar-like cheese) using enriched cream fermented by Bifidobacterium infantis, J. Dairy Sci. 82 (1999) 1081-1091.

[32] Dave R.I., Shah N.P., Effect of cysteine on the viability of yoghurt and probiotic bacteria in yoghurts made with commercial starter cultures, Int. Dairy J. 7 (1997) 537545.

[33] Dave R.I., Shah N.P., Ingredient supplementation effects on viability of probiotic bacteria in yoghurt, J. Dairy Sci. 81 (1998) 2804-2816.

[34] Davidson P.M., Doan C.H., Natamycin, in: Davidson P.M., Branen A.L. (Eds.),
Antimicrobials in Foods, Marcel Dekker Inc., New York, USA, 1993, pp. 395.

[35] Delbès C., Ali-Mandjee L., Montel M.C., Monitoring bacterial communities in raw milk and cheese by culture-dependent and -independent 16S rRNA gene-based analyses, Appl. Environ. Microbiol. 73 (2007) 1882-1891.

[36] Desai A.R., Powell I.B., Shah N.P., Survival and activity of probiotic lactobacilli in skim milk containing prebiotics, J. Food Sci. 69 (2004) 57-60.

[37] Dinakar P., Mistry V.V., Growth and viability of Bifidobacterium bifidum in Cheddar cheese, J. Dairy Sci. 77 (1994) 2854-2864.

[38] Domig K.J., Mayrhofer S., Zitz U., Mair C., Peterson A., Amtmann E., Mayer H.K., Kneifel W., Antibiotic susceptibility testing of Bifidobacterium thermophilum and Bifidobacterium pseudolongum strains: broth microdilution vs. agar disc diffusion assay, Int. J. Food Microbiol. 120 (2007) 191-195.

[39] Drider J., Fimland G., Héchard Y., McMullen L.M., Prévost H., The continuing story of class IIa bacteriocins, Microbiol. Mol. Biol. Rev. 70 (2006) 564-582.

[40] Ennahar S., Aoude-Werner D., Sorokine O., van Dorsselaer A., Bringel F., Hubert J.C., Hasselmann C., Production of pediocin AcH by Lactobacillus plantarum WHE92 isolated from cheese, Appl. Environ. Microbiol. 62 (1996) 4381-4387.

[41] Ennahar S., Assobhel O., Hasselmann C., Inhibition of Listeria monocytogenes in a smear-surface soft cheese by $L b$. plantarum WHE92, a pediocin AcH producer, J. Food Prot. 61 (1998) 186-191.

[42] European Commission (2002), Opinion of the Scientific Committee on Animal Nutrition on the criteria for assessing the safety of micro-organisms resistant to antibiotics of human clinical and veterinary importance, European Commission, Health and Consumer Protection Directorate General, Directorate C, Scientific Opinions, Brussels, Belgium.

[43] European Food Safety Authority (2004), EFSA Scientific Colloquium Summary Report, QPS: qualified presumption of safety of microorganisms in food and feed, European Food Safety Authority, Brussels, Belgium. 
[44] European Food Safety Authority (2005), Updating of the criteria used in the assessment of bacteria for resistance to antibiotics of human or veterinary importance, Question No. EFSA-Q2004-079 adopted on May 2005, The EFSA Journal 223, pp. $1-12$.

[45] FAO/WHO, Guidelines for the evaluation of probiotics in food, Food and Agricultural Organization of the United Nations and World Health Organization, Working Group Report, London, Ontario, Canada, 2002.

[46] Feld L., Schjorring S., Hammer K., Licht T.R., Danielsen M., Krogflet K., Wilcks A., Selective pressure affects transfer and establishment of a Lactobacillus plantarum resistance plasmid in the gastrointestinal environment, J. Antimicrob. Chemother. 61 (2008) 845-852.

[47] Filtenborg O.J., Frisvad C., Thrane U., Moulds in food spoilage, Int. J. Food Microbiol. 33 (1996) 85-102.

[48] Fleet G.H., Yeasts in dairy products, J. Appl. Bacteriol. 68 (1990) 199-211.

[49] Flórez A.B., Mayo B., Microbial diversity and succession during the manufacture and ripening of traditional, Spanish, blueveined Cabrales cheese, as determined by PCR-DGGE, Int. J. Food Microbiol. 110 (2006) 165-171.

[50] Flórez A.B., Delgado S., Mayo B., Antimicrobial susceptibility of lactic acid bacteria isolated from a cheese environment, Can. J. Microbiol. 51 (2005) 51-58.

[51] Fontaine L., Hols P., The inhibitory spectrum of thermophilin 9 from Streptococcus thermophilus LMD-9 depends on the production of multiple peptides and the activity of BlpG $\mathrm{St}_{\mathrm{St}}$, a thiol-disulfide oxidase, Appl. Environ. Microbiol. 74 (2008) 1102-1110.

[52] Foulquié Moreno M.R., Sarantinopoulos P., Tsakalidou E., De Vuyst L., The role and application of enterococci in food and health, Int. J. Food Microbiol. 106 (2006) $1-24$.

[53] Fox P.F., Wallace J.M., Formation of flavor compounds in cheese, Adv. Appl. Microbiol. 45 (1997) 17-85.

[54] Franz C.M.A.P., Stiles M.E., Schleifer K.H., Holzapfel W.H., Enterococci in foods - a conundrum for food safety, Int. J. Food. Microbiol. 88 (2003) 105-122.
[55] Gálvez A., Abriouel H., López R.L., Omar N.B., Bacteriocin-based strategies for food preservation, Int. J. Food Microbiol. 120 (2007) 51-70.

[56] Garde S., Avila M., Fernández-García E., Medina M., Nuñez M., Volatile compounds and aroma of Hispanico cheese manufactured using lacticin 481-producing Lactococcus lactis ssp. lactis INIA 639 as an adjunct culture, Int. Dairy J. 17 (2007) $717-726$.

[57] Garde S., Avila M., Gaya P., Medina M., Nuñez M., Proteolysis of Hispánico cheese manufactured using lacticin 481-producing Lactococcus lactis ssp. lactis INIA 639, J. Dairy Sci. 89 (2006) 840-849.

[58] Gardiner G., Stanton C., Lynch P.B., Collins J.K., Fitzgerald G., Ross R.P., Evaluation of Cheddar cheese as a food carrier for delivery of a probiotic strain to the gastrointestinal tract, J. Dairy Sci. 82 (1999) 1379-1387.

[59] Georgalaki M.D., Van den Berghe E., Kritikos D., Devreese B., Van Beeumen J., Kalantzopoulos G., De Vuyst L., Tsakalidou E., Macedocin, a food-grade lantibiotic produced by Streptococcus macedonicus ACA-DC 198, Appl. Environ. Microbiol. 68 (2002) 5891-5903.

[60] Giraffa G., Functionality of enterococci in dairy products, Int. J. Food Microbiol. 88 (2003) 215-222.

[61] Gobbetti M., Corsetti A., Smacchi E., Zocchetti A., De Angelis M., Production of Crescenza cheese by incorporation of bifidobacteria, J. Dairy Sci. 81 (1998) 37-47.

[62] Gobbetti M., De Angelis M., Di Cagno R., Minervini F., Limitone A., Cell-cell communication in food related bacteria, Int. J. Food Microbiol. 120 (2007) 34-45.

[63] Gomes A.M.P., Malcata F.X., Development of probiotic cheese manufactured from goat milk: response surface analysis via technological manipulation, J. Dairy Sci. 81 (1998) 1492-1507.

[64] Goulet V., de Valk H, Pierre O., Stainer F., Rocourt J., Vaillant V., Jacquet C., Desenclos J.C., Effect of prevention measures on incidence of human listeriosis, France 1987-1997, Emerg. Inf. Dis. 7 (2001) 983-898.

[65] Grattepanche F., Audet P., Lacroix C., Enhancement of functional characteristics of mixed lactic culture producing nisin $\mathrm{Z}$ 
and exopolysaccharides during continuous prefermentation of milk with immobilized cells, J. Dairy Sci. 90 (2007) 5361-5373.

[66] Guinane C.M., Cotter P.D., Hill C., Ross R.P., Microbial solutions to microbial problems; lactococcal bacteriocins for the control of undesirable biota in food, J. Appl. Microbiol. 98 (2005) 1316-1325.

[67] He T., Priebe M.G., Zhong Y., Huang C., Harmsen H.J.M., Raang G.C., Antoine J.M., Welling G.W., Vonk R.J., Effects of yogurt and bifidobacteria supplementation on the colonic microbiota in lactoseintolerant subjects, J. Appl. Microbiol. 104 (2008) 595-604.

[68] Holzapfel W.H., Haberer P., Geisen R., Björkroth J., Schillinger U., Taxonomy and important features of probiotic microorganisms in food and nutrition, Am. J. Clin. Nutr. 73 (2001) 365-373.

[69] Hummel A.S., Hertel C., Holzapfel W.H., Franz C.M.A., Antibiotic resistances of starter and probiotic strains of lactic acid bacteria, Appl. Environ. Microbiol. 73 (2007) 730-739.

[70] Huys G., D’Haene K., Collard J.M., Swings J., Prevalence and molecular characterization of tetracycline resistance in Enterococcus isolates from food, Appl. Environ. Microbiol. 70 (2004) 1555-1562.

[71] Jan G., Rouault A., Maubois J.L., Acid stress susceptibility and acid adaptation of Propionibacterium freudenreichii subsp. sherrmanii, Lait 80 (2000) 325-336.

[72] Jayamanne V.S., Adams M.R., Determination of survival, identity and stress resistance of probiotic bifidobacteria in bioyoghurts, Lett. Appl. Microbiol. 42 (2006) 189-194.

[73] Kastner S., Perreten V., Bleuler H., Hugenschmidt G., Lacroix C., Meile L., Antibiotic susceptibility patterns and resistance genes of starter cultures and probiotic bacteria used in food, Syst. Appl. Microbiol. 29 (2006) 145-155.

[74] Kirkup B.C., Bacteriocins as oral and gastrointestinal antibiotics: theoretical considerations, applied research, and practical applications, Curr. Med. Chem. 27 (2006) 3335-3350.

[75] Klaenhammer T.R., Genetics of bacteriocins produced by lactic acid bacteria, FEMS Microbiol. Rev. 12 (1993) 39-85.
[76] Klare I., Konstabel C., Werner G., Huys G., Vankerckhoven V., Kahlmeter G., Hildebrandt B., Müller-Bertling S., Witt W., Goossens H., Antimicrobial susceptibilities of Lactococcus human isolates and cultures intended for probiotic or nutritional use, J. Antimicrob. Chemother. 59 (2007) 900-912.

[77] Koch S.R., Effects of fermentation conditions on viability, physiological and technological characteristics of autolytic dried direct vat set lactic starter cultures, Ph.D. thesis, 2006, ETH, Zürich, Switzerland.

[78] Lacroix C., Grattepanche F., Doleyres Y., Bergmaier D., Immobilized cell technologies for the dairy industry, in: Nevidovic V., Willaert R. (Eds.), Applications of Cell Immobilization Biotechnology, Series: Focus on Biotechnology, Vol. 8B, Springer-Verlag, Berlin, Germany, pp. 295-319.

[79] Lacroix C., Yildirim S., Fermentation technologies for the production of probiotics with high viability and functionality, Curr. Opin. Biotechnol. 18 (2007) 176-183.

[80] Lazzi C., Rossetti L., Zago M., Neviani E., Giraffa G., Evaluation of bacterial communities belonging to natural whey starters for Grana Padano cheese by length heterogeneity-PCR, J. Appl. Microbiol. 96 (2004) 481-490.

[81] Levy S.B., Marshall B., Antibacterial resistance worldwide: causes, challenges and responses, Nature Med. 10 (2004) 122-129.

[82] Little C.L., Rhoades J.R., Sagoo S.K., Harris J., Greenwood M., Mithani V., Grant K., McLauchlin J., Microbiological quality of retail cheeses from raw, thermized or pasteurized milk in the UK, Food Microbiol. 25 (2008) 304-312.

[83] Loessner M., Guenther S., Steffan S., Scherer S., A pediocin-producing Lactobacillus plantarum strain inhibits Listeria monocytogenes in a multispecies cheese surface microbial ripening consortium, Appl. Environ. Microbiol. 69 (2003) 18541857.

[84] Magnusson J., Schnürer J., Lactobacillus coryniformis subsp. coryniformis strain $\mathrm{Si} 3$ produces a broad-spectrum proteinaceous antifungal compound, Appl. Environ. Microbiol. 67 (2001) 1-5.

[85] Maoz A., Mayr R., Scherer S., Temporal stability and biodiversity of two complex 
antilisterial cheese-ripening microbial consortia, Appl. Environ. Microbiol. 69 (2003) 4012-4018.

[86] Martínez-Cuesta M.C., Peláez C., Juárez M., Requena T., Autolysis of Lactococcus lactis ssp. lactis and Lactobacillus casei ssp. casei. Cell lysis induced by a crude bacteriocin, Int. J. Food Microbiol. 38 (1997) 125-131.

[87] Martínez-Cuesta M.C., Requena T., Peláez C., Use of a bacteriocin-producing transconjugant as starter in acceleration of cheese ripening, Int. J. Food Microbiol. 70 (2001) 79-88.

[88] Martínez-Cuesta M.C., Requena T., Peláez C., Cell membrane damage induced by lacticin 3147 enhances aldehyde formation in Lactococcus lactis IFLP730, Int. J. Food Microbiol. 109 (2006) 1989-204.

[89] Mc Brearty S., Ross R.P., Fitzgerald G.F., Collins J.K., Wallace J.M., Stanton C., Influence of two commercially available bifidobacteria cultures on Cheddar cheese quality, Int. Dairy J. 11 (2001) 599-610.

[90] Meile L., Le Blay G., Thierry A., Safety assessment of dairy microorganisms: Propionibacterium and Bifidobacterium, Int. J. Food Microbiol. 126 (2008) 316320.

[91] Miescher Schwenninger S., Meile L., A mixed culture of Propionibacterium jensenii and Lactobacillus paracasei subsp. paracasei inhibits food spoilage yeasts, Syst. Appl. Microbiol. 27 (2004) 229-237.

[92] Miescher Schwenninger S., Von Ah U., Niederer B., Teuber M., Meile L., Detection of antifungal properties in Lactobacillus paracasei subsp. paracasei SM20, SM29, and SM63 and molecular typing of the strains, J. Food Prot. 68 (2005) 111-119.

[93] Millet L., Didienne R., Tessier L., Montel M.C., Control of Listeria monocytogenes in raw milk cheeses, Int. J. Food Microbiol. 108 (2006) 105-114.

[94] Morency H., Mota-Meira M., LaPointe G., Lacroix C., Lavoie M.C., Comparison of the activity spectra against pathogens of bacterial strains producing a mutacin or a lantibiotic, Can. J. Microbiol. 47 (2001) 322-331.

[95] Morgan S.M., O’Sullivan L., Ross R.P., Hill C., The design of a three strain starter system for Cheddar cheese manufacture exploiting bacteriocin-induced starter lysis, Int. Dairy J. 12 (2002) 985-993.
[96] Mounier J., Monnet C., Vallaeys T., Arditi R., Sarthou A.S., Helias A., Irlinger F., Microbial interactions within a cheese microbial community, Appl. Environ. Microbiol. 74 (2008) 172-181.

[97] Muñoz A., Ananou S., Gálvez A., Martínez-Bueno M., Rodríguez A., Maqueda M., Valdivia E., Inhibition of Staphylococcus aureus in dairy products by enterocin AS-48 produced in situ and ex situ: bactericidal synergism with heat, Int. Dairy J. 17 (2007) 760-769.

[98] Naghmouchi K., Kheadr E., Lacroix C., Fliss I., Class I/Class IIa bacteriocin crossresistance phenomenon in Listeria monocytogenes, Food Microbiol. 24 (2007) 718727.

[99] Nes I.F., Diep D.B., Holo H., Bacteriocin diversity in Streptococcus and Enterococcus, J. Bacteriol. 189 (2007) 1189-1198.

[100] Niku-Paavola M.L., Laitila A., MattilaSandholm T., Haikara A., New types of antimicrobial compounds produced by Lactobacillus plantarum, J. Appl. Microbiol. 86 (1999) 29-35.

[101] Nuñez M., Rodríguez J.L., García E., Gaya P., Medina M., Inhibition of Listeria monocytogenes by enterocin 4 during the manufacture and ripening of Manchego cheese, J. Appl. Microbiol. 83 (1997) 617-677.

[102] O’Sullivan L., O'Connor E.B., Ross R.P., Hill C., Evaluation of live-cultureproducing lacticin 3147 as a treatment for the control of Listeria monocytogenes on the surface of smear-ripened cheese, J. Appl. Microbiol. 100 (2006) 135-143.

[103] Ogier J.C., Lafarge V., Girard V., Rault A., Maladen V., Gruss A., Leveau J.Y., Delacroix-Buchet A., Molecular fingerprinting of dairy microbial ecosystems by use of temporal temperature and denaturing gradient gel electrophoresis, Appl. Environ. Microbiol. 70 (2004) 5628-5643.

[104] Ong L., Henriksson A., Shah N.P., Development of probiotic Cheddar cheese containing Lactobacillus acidophilus, Lb. casei, Lb. paracasei and Bifidobacterium spp. and the influence of these bacteria on proteolytic patterns and production of organic acids, Int. Dairy J. 16 (2006) 446-456.

[105] Ong L., Henriksson A., Shah N.P., Proteolytic pattern and organic acid profiles of probiotic Cheddar cheese 
as influenced by probiotic strains of Lactobacillus acidophilus, Lb. paracasei, Lb. casei or Bifidobacterium spp., Int. Dairy J. 17 (2007) 67-78.

[106] Ouwehand A.C., The probiotic potential of propionibacteria, in: Salminen S., von Wright A., Ouwehand A. (Eds.), Lactic Acid Bacteria: Microbiology and Functional Aspects, Marcel Dekker Inc., New-York, USA, 2004, pp. 159-174.

[107] Ouwehand A.C., Salminen S., Isolauri E., Probiotics: an overview of beneficial effects, Antonie van Leeuwenhoek 82 (2002) 279-289.

[108] Peláez C., Requena T., Exploiting the potential of bacteria in the cheese ecosystem, Int. Dairy J. 15 (2005) 831-844.

[109] Perreten V., Resistance in the food chain and in bacteria from animals: relevance to human infections, in: White D.G., Alekshun N.V., McDermott P.F. (Eds.), Frontiers in Antibiotic Resistance: A Tribute to Stuart B. Levy, ASM, Washington DC, USA, 2005, pp. 446-464.

[110] Perreten V., Schwarz F., Cresta L., Boeglin M., Dasen G., Teuber M., Antibiotic resistance spread in food, Nature 389 (1997) 801-802.

[111] Perreten V., Vorlet-Fawer L., Slickers P., Ehricht R., Kuhnert P., Frey J., Microarraybased detection of 90 antibiotic resistance genes of Gram-positive bacteria, J. Clin. Microbiol. 43 (2005) 2291-2302.

[112] Phillips M., Kailasapathy K., Tran L., Viability of commercial probiotic cultures (L. acidophilus, Bifidobacterium sp., L. paracasei and L. rhamnosus) in Cheddar cheese, Int. J. Food Microbiol. 108 (2006) 276-280.

[113] Rademaker J.L.W., Peinhopf M., Rijnen L., Bockelmann W., Noordman W.H., The surface microflora dynamics of bacterial smear-ripened Tilsit cheese determined by T-RFLP DNA population fingerprint analysis, Int. Dairy J. 15 (2005) 785-794.

[114] Randazzo C.L., Torriani S., Akkermans A.D.L., de Vos W.M., Vaughan E.E., Diversity, dynamics, and activity of bacterial communities during production of an artisanal sicilian cheese as evaluated by $16 \mathrm{~S}$ rRNA analysis, Appl. Environ. Microbiol. 68 (2002) 1882-1892.

[115] Rodríguez J.M., Martínez M.I., Horn N., Dodd H.M., Heterologous production of bacteriocins by lactic acid bacteria, Int. J. Food Microbiol. 880 (2003) 101-116.

[116] Rollema H.S., Kuipers O.P., Both P., de Vos W.M., Siezen R.J., Improvement of solubility and stability of the antimicrobial peptide nisin by protein engineering, Appl. Environ. Microbiol. 61 (1995) 2873-2878.

[117] Ross P.R., Stanton C., Hill C., Fitzgerald G.F., Coffey A., Novel cultures for cheese improvement, Trends Food Sci. Technol. 11 (2000) 96-104.

[118] Roy D., Technological aspects related to the use of bifidobacteria in dairy products, Lait 85 (2005) 39-56.

[119] Ryan M.P., Rea M.C., Hill C., Ross R.P., An application in cheddar cheese manufacture for a strain of Lactococcus lactis producing a novel broad-spectrum bacteriocin, lacticin 3147, Appl. Environ. Microbiol. 62 (1996) 612-619.

[120] Rychlik M., Bosset J.O., Flavour and off-flavour compounds of Swiss Gruyère cheese. Identification of key odorants by quantitative instrumental and sensory studies, Int. Dairy J. 11 (2001) 903-910

[121] Salminen S., von Wright A., Morelli L., Marteau P., Brassart D., de Vos W.M., Fondén R., Saxelin M., Collins K., Mogensen G., Birkeland S.E., MattilaSandholm T., Demonstration of safety of probiotics - a review, Int. J. Food Microbiol. 44 (1998) 93-106.

[122] Salyers A.A., Gupta A., Wang Y., Human intestinal bacteria as reservoirs for antibiotic resistance genes, Trends Microbiol. 12 (2004) 412-416.

[123] Sanders M.E., Walker D.C., Walker K.M., Aoyama K., Klaenhammer T.R., Performance of commercial cultures in fluid milk applications, J. Dairy Sci. 79 (1996) 943-955.

[124] Saubusse M., Millet L., Delbès C., Callon C., Montel M.C., Application of Single Strand Conformation Polymorphism-PCR method for distinguishing cheese bacterial communities that inhibit Listeria monocytogenes, Int. J. Food Microbiol. 116 (2007) 126-135.

[125] Schnürer J., Magnusson J., Antifungal lactic acid bacteria as biopreservatives, Trends Food Sci. Technol. 16 (2005) 70-78.

[126] Shah N.P., Lankaputhra W.E.V., Britz M.L., Kyle W.S.A., Survival of Lactobacillus acidophilus and Bifidobacterium bifidum 
in commercial yoghurt during refrigerated storage, Int. Dairy J. 5 (1995) 515-521.

[127] Sjögren, J., Magnusson J., Broberg A., Schnürer J., Kenne L., Antifungal 3-hydroxy fatty acids from Lactobacillus plantarum MiLAB 14, Appl. Environ. Microbiol. 69 (2003) 7554-7557.

[128] Smit G., Smit B.A., Engels W.J.M., Flavour formation by lactic acid bacteria and biochemical flavour profiling of cheese products, FEMS Microbiol. Rev. 29 (2005) 591610.

[129] Smits G.J., Brul S., Stress tolerance in fungi - to kill a spoilage yeast, Curr. Opin. Biotechnol. 16 (2005) 225-230.

[130] Sobrino-López A., Martín-Belloso O., Use of nisin and other bacteriocins for preservation of dairy products, Int. Dairy J. 18 (2008) 329-343.

[131] Sousa M.J., Ardö Y., McSweeney P.L.H., Advances in the study of proteolysis during cheese ripening, Int. Dairy J. 11 (2001) 327-345

[132] Ström K., Sjögren J., Broberg A., Schnürer J., Lactobacillus plantarum MiLAB 393 produces the antifungal cyclic dipeptides cyclo(L-Phe-L-Pro) and cyclo(L-Phetrans-4-OH-L-Pro) and 3-phenyllactic acid, Appl. Environ. Microbiol. 68 (2002) 43224327.

[133] Suomalainen T.H., Mäyra-Mäkinen A.M., Propionic acid bacteria as protective cultures in fermented milks and breads, Lait 79 (1999) 165-174.

[134] Talwalkar A., Kailasapathy K., The role of oxygen in the viability of probiotic bacteria with reference to L. acidophilus and Bifidobacterium spp., Curr. Issues Intest. Microbiol. 5 (2004) 1-8.
[135] Teuber M., Meile L., Schwarz F., Acquired antibiotic resistance in lactic acid bacteria from food, Antonie van Leeuwenhoek 76 (1999) 115-137.

[136] Tosi L., Berruti G., Danielsen M., Wind A., Huys G., Morelli L., Susceptibility of Streptococcus thermophilus to antibiotics, Antonie Van Leeuwenhoek 92 (2007) 21-28.

[137] Tsakalidou E., Zoidou E., Pot B., Wassill L., Ludwig W., Devriese L.A., Kalantzopoulos G., Schleifer K.H., Kersters K., Identification of streptococci from Greek Kasseri cheese and description of Streptococcus macedonicus sp. nov., Int. J. Syst. Bacteriol. 48 (1998) 519-527.

[138] Van den Berghe E., Skourtas G., Tsakalidou E., De Vuyst L., Streptococcus macedonicus ACA-DC 198 produces the lantibiotic, macedocin, at temperature and $\mathrm{pH}$ conditions that prevail during cheese manufacture, Int. J. Food Microbiol. 107 (2006) 138-147.

[139] Vinderola C.G., Prosello W., Ghilberto D., Reinheimer J.A., Viability of probiotic (Bifidobacterium, Lactobacillus acidophilus and Lactobacillus casei) and nonprobiotic microflora in Argentinian Fresco cheese, J. Dairy Sci. 83 (2000) 1905-1911.

[140] Yang Z., Suomalainen T., Mäyrä-Mäkinen A., Huttunen E., Antimicrobial activity of 2-pyrrolidone-5-carboxylic acid produced by lactic acid bacteria, J. Food Prot. 60 (1997) 786-790.

[141] Yilmaztekin M., Ozer B.H., Atasoy F., Survival of Lactobacillus acidophilus LA-5 and Bifidobacterium bifidum BB-02 in white brined cheese, Int. J. Food Sci. Nutr. 55 (2004) 53-60. 